\title{
VIRAL PANDEMICS, TRANSHUMANISM AND BIO-ART GADGETS: A LACANIAN READING OF DAN BROWN'S INFERNO
}

\author{
Hub Zwart \\ University of Nijmegen, Faculty of Science \\ Department of Philosophy and Science Studies \\ Postbus 9010, NL-6500 GL Nijmegen \\ Tel.: ++/31/(0)24 3652038, h.zwart@ science.ru.nl
}

Summary: This article reads Dan Brown's best-selling novel Inferno (2013) not as a cinematic techno-thriller, but as a "science novel": a literary document that allows us to discern some of the tensions, paradoxes and inner dynamics of virology as a contemporary ("hyper-scientific") biomedical research field. It will be argued that Inferno can help us to "assess the present" by pointing out what we find so intriguing and uncanny about virology and its model organism of choice: the potentially lethal virus. To highlight its cultural relevance, I will approach the novel from a Lacanian perspective. Specifically, I will use Lacan's "four discourses" to assess the various roles and positions that determine its basic structure. On the one hand, the novel's key characters function as experts (representing expertise in academic research fields such as molecular life sciences, global health policy and cultural studies), giving voice to what Lacan refers to as "university discourse". On the other hand, they are tormented individuals, suffering from a range of pathologies and symptoms which allegedly have become endemic in contemporary society ("hysterical discourse"). But the novel also gives the floor to the "Master discourse": the authoritative voice which apparently knows the truth about the current human condition, articulating a vision of the future, encasing its prophetic messages in intriguing bio-art gadgets. In Inferno, these discourses are challenged/ subverted/altered by "analytical" discourse, putting the key characters on the track of their "object $a$ ", the cause of their desire. Thus, a Lacanian reading allows us to discern how Inferno reflects, in a condensed and emblematic way, the public discontent in contemporary "hyperscience", under the sway of the potentially lethal virus as its fascinating and commanding "object $a$ ".

Key words: Psychoanalysis of Science, Lacanian Theory, Science Novels, Virology, Dual Use, Philosophy of Science, Dan Brown, Inferno.

Received: August 8 ${ }^{\text {th }}, 2014 ;$ Accepted: December $9^{\text {th }}, 2014$. 
Introduction

On Tuesday morning, May 28, 2013, in a conference room at the Hilton Hotel in Rotterdam, virologist Ab Osterhaus opened the ethics session of the annual EMPERIE meeting by introducing his colleague Ron Fouchier as keynote speaker with the following quote, displayed on a power-point slide, inviting participants to guess its source:

"Just recently, two very respected virologists - Fouchier and Kawaoka - had created a highly pathogenic mutant H5N1 virus. Despite the researchers' purely academic intent, their new creation possessed certain capabilities that had alarmed biosecurity specialists and had created a firestorm of controversy online..."

The acronym EMPERIE refers to the European Management Platform for Emerging and Re-emerging Infectious disease Entities, an international research consortium led by Osterhaus. Fouchier (professor of virology at the Erasmus Medical Centre in Rotterdam) is one of its Principal Investigators. Its objective is "to contribute to effectively countering the potential public health threat caused by new and emerging infectious diseases in Europe by establishing a powerful network capable of structural and systematic prediction, identification, modelling and surveillance of infectious diseases health threats and pathogens". ${ }^{1}$ The quote cited above was taken from Dan Brown's latest novel Inferno (Brown, 2013: 452) which had been released just two weeks before the meeting (on May 14). The reference to Fouchier's work is more than an aside. Virology is the key topic in Brown's book.

For me, this mutual spillover from cutting-edge virology research into best-selling novel-writing and back (from non-fiction to fiction and back) is more than merely an anecdote. Rather, I see it as a compelling rebuttal of the (sufficiently discredited?) idea that science and literature are to be seen as segregate compartments of culture. Apparently, prominent scientists and prominent novelists keep track of each other's work, so that scientists are cited in novels, and novelists are quoted at scientific meetings in return, addressing similar issues (simultaneously more or less), albeit using different methods

1. http://www.emperie.eu/emp/ consulted: August 2014. 
and working from different perspectives. Although Inferno is evidently a work of fiction, and virology is essentially non-fiction, both types of discourse may be brought into a meaningful dialogue. The fiction/non-fiction divide is a fluid one. There is a "fictional" (imaginative) dimension to virology (notably when possible scenarios of potential pandemics are fleshed out) and a non-fiction dimension to novels such as Inferno (addressing social and cultural impacts of cutting-edge research practices).

Inferno can be seen as a thriller, engaging readers in exiting pursuits and implausible escapes, employing a mixture of cultural history and suspense which has become the author's trade mark, and involving a number of stock characters: a mad genius, a number of intriguing but fairly dangerous women, and Robert Langdon, Harvard professor of "symbology", the author's male protagonist of choice. As such, the novel provides ample material for a cinematic version. ${ }^{2}$

Inferno may also be read, however, as a science novel, a genre that uses literary techniques to probe and outline some of the tensions, paradoxes and inner dynamics of contemporary research fields such as virology, thus providing a window into the social and cultural dimensions of biomedical research. ${ }^{3}$ As a science novel, Inferno may help us to understand what it is we find so intriguing and uncanny about virology. It may deepen our understanding of (public responses to) this field. Science novels emerge in the boundary zone between laboratory life and the public sphere. They keep track of what is happening in research practices, while giving voice to expectations and concerns of broader audiences, but also of scientists themselves (Zwart, 2008; 2014). By presenting some of the challenges of thriving global research areas such as virology in an imaginative way, they fuel reflection among scientists, science students and the public at large. In other words, beyond its entertainment value as a thriller, Inferno may

2. Two earlier novels by Dan Brown (The Da Vinci Code and Angels \& Demons) became movies, while a movie version of Inferno has been announced.

3. I use the label "science novel" to refer to a (loosely defined) genre of fiction also known as "lab lit". It is different from historical science novels, as well as from science fiction, in that it contains (semi-realistic) portrayals of contemporary scientists and the (usually high-tech) research practices they are involved in (Rohn, 2006). Depending on the amount of drama and suspense, they may also be listed as "techno-thrillers". The first real science novel was Arrowsmith by Sinclair Lewis, devoted to the bacterium-eating virus, the bacteriophage. A prominent recent example is Mendel's Dwarf by Simon Mawer, although this novel (like a literary double helix) combines two genres: the historical and the contemporary science novel (cf Mawer, 2005). 
be seen as a "condensation" of the present, a document that may contribute to the assessment of the current Zeitgeist.

In order to bring its intellectual relevance to the fore, I will read it from a psychoanalytical, notably Lacanian angle. Building on Lacan's "four discourses", I will show how in Inferno "analytical discourse" subverts and destabilises the others types of discourse (the "master discourse", the "university discourse" and the "hysterical discourse") represented in the novel. But before elaborating the "method" and design of this paper, let me first briefly summarise the (fairly labyrinthine) story line.

\section{Plot summary}

The novel's key protagonist (the novel's ego) is Robert Langdon, Harvard expert in ancient and medieval symbolism, who also figured in previous best-sellers by Brown (The Lost Symbol, The Da Vinci Code, Angels \& Demons). The tale is set in three cities: picturesque highlights of religious architecture, and former metropolises of grand politics, merchandise and art, namely Florence, Venice and Istanbul. The story takes us stepwise from West to East and from the Renaissance into the medieval and byzantine era. Brown's novel closely follows the well-trodden paths of tourist itineraries, providing concise information on famous monuments passed along the way, so that his book at times displays the typical genre features of a tourist guide.

At the start of the novel, Robert Langdon, bachelor, scholar of international renown and Harvard professor of a non-existent academic discipline called "symbology", wakes up in a hospital room surrounded by medical equipment, haunted by unsettling nightmares and suffering from amnesia. The skyline (visible through the window) informs him that he is in Florence. Sienna Brooks, a tall, athletic physician sitting at his bedside, questions him about his mental problems, carefully taking notes, like a professional clinical psychologist (or even a psychoanalyst) would do ("Any idea what might have sparked such a frightening vision?", Brown, 2013: 12). All of a sudden, a strong, powerfully built woman, clad in black leather and advancing "like a panther stalking its prey", bursts into the room, armed with a silenced gun. With the help of Sienna Brooks, the weakened, semi-conscious Langdon manages to escape: the first in a long series of escapades and frantic pursuits, with hunters turning into 
targets and vice versa, through labyrinths and secret passages built into ancient monuments.

Meanwhile, on board a luxury yacht named The Mendacium, an employee has uploaded an unsettling video submitted by a mysterious client, featuring a strange figure wearing a plague mask and announcing, in an uncanny soliloquy, that he is about to dramatically save/destroy the world with the help of a weird gelatinous liquid, contained in an underwater balloon in a subterranean pond.

After their escape from the hospital, Langdon tells Sienna about his hallucinations (a veiled woman, a throng of dead people and a set of writhing, naked, protruding legs) and she responds by saying that the

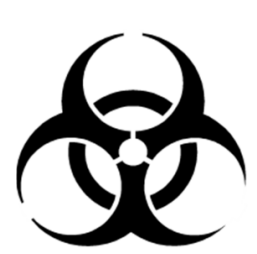
uncanny scene reminds her of a notorious quote from Robert Oppenheimer, designer of the atomic bomb: "I am Vishnu, destroyer of world" (Ibid.: 45). In Langdon's jacket a bio-tube is found carrying the biohazard symbol and containing luminescent bugs that project a grim picture on the wall: the Map of Hell, painted by Renaissance artist Botticelli and based on Dante's poem Inferno (Part One of his three-volume masterpiece, the Divine Comedy). This bio-art gadget was produced by the mad genius of the novel: the Swiss millionaire biochemist Bertrand Zobrist who believes that humankind is on the brink of extinction due to overpopulation caused by exponential global population growth. He figures quite prominently on the World Health Organisation's watch list of potential bioterrorists and has used his scientific genius and biotechnical dexterity to develop a viral vector to cull humanity ("thin the herd", as he himself phrases it, Ibid.: 177, 295) and save the planet. He intends to launch a cataclysmic pandemic similar to the late medieval Black Death, arguing that this dramatic event, with its enormous death toll, actually proved a blessing in disguise, making the Renaissance possible (Ibid.: 48). ${ }^{4}$ Zobrist is not only a world-famous biochemistry celebrity, but also a Dante adept, seeing the latter's Inferno as a prophecy, a fusion of knowledge and imagination, a literary anticipation of what the medieval world would have looked like if population growth would have been allowed to continue uncurbed, with its visions of huddled masses wallowing in their excrement.' Thus, for Zobrist, the late medieval Plague actually constitutes a paradigm for action: a massive culling, orchestrated by nature herself:

4. A view that has been taken by historians as well (Bowsky, 1971; DeWitte, 2014).

5. Brueghel's Triumph of Death is mentioned as a like-minded artwork (Brown, 2013: 382). 
a kind of natural self-purging of human kind (this was also how Renaissance philosopher Machiavelli saw it, Ibid.: 104). Mass global tourism (the immense human crowds swarming cities like Venice on a daily basis) functions as a symptom of overpopulation.

Langdon eventually finds out that Sienna is not an ordinary physician at all, but a zealous follower (and former lover) of Zobrist, a firm believer in the latter's ideas. ${ }^{6}$ In support of her mysterious mentor, she argues that humankind has collectively fallen victim to a defence mechanism known as denial (Ibid.: 214): we see the impending catastrophe coming, but choose to ignore the signs and mistakenly believe ourselves to be "immune" to disaster (Ibid.: 215). Indeed, denial has become a global psychic "pandemic" in its own right (Ibid.: 463). And this notably applies to powerful agencies such as the WHO, represented in the novel by director Elisabeth Sinskey. Instead of promoting alertness as a global early warning system, these agencies act as censors, keeping unsettling information away from public consciousness. When Zobrist is about to be arrested by WHO special agents, he commits suicide by jumping off an ancient tower in Florence, but the events unleashed by him cannot be undone. The vector virus - his "masterpiece", the opus that will change the world (Ibid.: 76), the modern scientific counterpart to Dante's Inferno - has already been let loose inside the "sunken palace", the novel's Ground Zero (Ibid.: 381): the famous cistern beneath the Hagia Sophia in Istanbul. ${ }^{7}$ From there, the airborne virus has already started to propagate around the globe, using the exponential growth of viruses to cull the exponential growth of humans, infecting their DNA (Ibid.: 437), making one in every three humans infertile: just enough to bend the population curve. Containment of the invisible Plague is no longer an option. Without anybody noticing it, the invisible catastrophe, caused by minuscule lab-bred pathogens, has already taken place, although it will take decades before its (beneficial?) impact will become truly noticeable in the form of decreasing birth rates.

6. Like Zobrist, Sienna believes in the Population Apocalypse Equation, i.e., the mathematical idea that population growth will cause an "apocalyptic collapse", a "mass extinction event". "The best thing that ever happened to Europe", she argues, "was the Black Death". Through its long-term socioeconomic benefits, it functioned as "a catalyst for bringing about the Renaissance" (Brown, 2013: 177). Cf the famous soliloquy by Orson Wells (as the penicillin criminal in The Third Man) about the relationship between disruptive catastrophes and Renaissance art.

7. A tribute to the fact that Istanbul had once been point zero, from where traffic and civilisation spread and distances were measured (Brown, 2013: 383). 
We as a species simply have become too prolific, Zobrist and his followers argue, so that something had to be done. The disconcerting mathematical truth of the exponential growth curve is indisputable: the collapse of our species is coming (Ibid.: 367). In short, Zobrist underpins his decision to launch a global genetic engineering project with an ethical algorithm. In the meantime, the Transhumanist movement (of which Zobrist was an ardent, radical member) is about to "go viral" as well, pervading the mainstream of thought (Ibid.: 453), using the extra time provided by Zobrist's Plague to come up with a more sustainable solution for fixing our most fatal evolutionary flaw: our uncontrollable desire to reproduce. This will be done by modifying our genetic propensity to propagate, using viral vectors to "enhance" the human genome.

Moreover, as Sienna explains, Zobrist is not an exception. He is a pioneer, representing a new way of thinking and acting. In laboratories around the globe, bioscience is moving ahead at an unsettling pace, and genetic engineering has irreversibly become part of evolution. Many will follow in his footsteps to re-engineer our human future including Ron Fouchier and his team, as Dan Brown sees it.

\section{Conceptual framework and design: the four discourses}

Inferno addresses a number of key issues in contemporary biomedicine and health policy, ranging from infectious diseases, endemic depression and involuntary childlessness up to genetic engineering and human enhancement. Indeed, three of the four principal characters are directly involved in biomedical activities, namely Sienna Brooks (the idealistic practicing physician), Elisabeth Sinskey (the global health policy expert) and Bertrand Zobrist (the expert in molecular mechanisms of infectious disease). They are not only professionals, however, but patients themselves as well, with dramatic case histories, involving a whole spectrum of psychic and medical problems (childhood traumas, claustrophobia, depression, asthma, infertility, persecution anxiety, and so on).

As a consequence, Inferno is pervaded by instances of therapy and analytical discourse, addressing this plethora of symptoms. Indeed, analytic (therapeutic) relationships constitute the novel's basic structure. These "therapies" are not only directed at individuals, moreover, but also at the social roles and research fields they represent. Thus, some of the inhibitions and tensions of hypermodern society as such are fleshed out and placed in a temporal perspective. 
Biomedical research has become so astonishingly successful that humanity must learn to come to terms with the uncanny powers over life entailed in emerging "hyper-sciences" such as virology: that is the basic moral message of the novel. ${ }^{8}$

In other words, in Inferno, "therapist" (analyst) and "patient" (analysand) are important roles. Interestingly however, the key characters listed above play multiple roles, with "patients" suddenly assuming the role of "therapist" and vice versa. These roles circulate among the key players: they are transferable from one person to the next. Initially, for instance, Robert Langdon is the patient, with Sienna Brooks (the mysterious physician) as his analyst. But as the novel progresses, these roles are reversed, so that Robert becomes the therapist and Sienna his patient.

Moreover, therapist and patient are not the only roles in circulation. Besides being a tormented subject suffering from various symptoms ("patient"), as well as an impromptu analyst ("therapist"), Robert Langdon is first of all a scholar: a university expert, called upon to decipher encoded messages. And while Bertrand Zobrist is initially introduced as a hysterical psychopath, he increasingly functions as a "Master" voice who knows the truth about the current human condition. In fact, in the course of the novel, various roles are enacted by Zobrist:

-Zobrist the scientific expert: a biochemist of international renown; -Zobrist the psychopath: a bioterrorist, threatening the world with destruction;

-Zobrist the visionary: an authoritative representative of the transhumanist philosophy of the future;

-Zobrist the therapist: fighting denial as an endemic societal condition.

Elisabeth Sinskey likewise plays a variety of roles. She is first of all a health policy expert, specialised in global health issues, but she also functions as therapist for Zobrist (as his audience of choice, the ear he desires to reach). But she also is a patient herself, suffering

8. I use the term "hyperscience" as the type of science that typifies hypermodernity: a style of research that uses and combines the latest high-tech technologies for understanding and controlling, but most of all manipulating biological processes down to the molecular level, where life and technology increasingly seem to merge. 
from unsettling symptoms of her own, mostly as a result of her attitude of "denial".

These roles (their distributions, reversals and circulations) constitute the basic structure of the novel. To bring this dynamic structure to the fore, I will analyse Inferno with the help of the "four discourses" as developed by Jacques Lacan (1991 [1969-1970]):

-the master discourse (represented notably by Zobrist, the visionary prophet);

-the university discourse (represented by experts such as Langdon and Sinskey);

-the hysterical discourse (to which all the main characters adhere sooner or later);

-the analytical discourse (pervading the novel as such).

Lacan develops these four discourses on the basis of the following scheme:

\begin{tabular}{c|c} 
Agent & Other \\
\hline Truth & Product
\end{tabular}

In these four positions, four variables can be inserted:

$\mathrm{S}_{1}$ - the "Master" signifier, the authoritative voice (the genius, the legislator, the sovereign, etc.) who knows the truth, masters the situation and defies standard normal discourse;

$\mathrm{S}_{2}$ - expert knowledge, of laboratory researchers, for instance, but also of officials or other representatives of established expertise, using standard insights and skills to process various forms of input; $\$-$ the divided, craving subject, suffering from a lack that gives rise to various symptoms, in need of therapy and in search of a Master;

Finally, the "object $a$ ", the cause and focus of our desire, our cupido sciendi (our will to know), as indicated by the Lacanian "matheme" of desire $(\$ \diamond a)$.

Permutations of this scheme give rise to four types of discourse. For instance: if $S_{1}$ (the master signifier) is placed in the dominant (upper-left) position (as Agent), this results in what Lacan refers to as the "master discourse": 


\begin{tabular}{c|c}
$\mathrm{S}_{1}$ & $\mathrm{~S}_{2}$ \\
\hline$\$$ & $a$
\end{tabular}

In Inferno, the Master-role is represented by Zobrist, who speaks with an authoritative voice (as science celebrity and Transhumanist prophet). His messages convey a repressed, latent desire (the urge to drastically curb population growth) fuelled by an unconscious, unsettling truth (the emerging catastrophe: lower-left position), and they are directed towards representatives of expert knowledge as "Other" ( $\mathrm{S}_{2}$ : upper-right), such as Sinskey (the WHO official) or Langdon (the university scholar). While Sinskey is Zobrist's audience of choice, Langdon is called upon to interpret, process, elaborate and transmit his encrypted truth games. In the course of these interactions, a series of intriguing, captivating bio-art objects are produced, functioning as objects $a$ (lower-right).

A rival interpretation sees Zobrist not as an authoritative Master voice, but rather as a craving, tormented subject, a dangerous psychopath (\$). In his case, $\$$ is placed in the upper-left position of the Agent, resulting in the hysterical discourse (which will be discussed below).

The basic scheme can be permutated, turned backwards and forwards. Every turn (over 90 degrees) results in a different type of discourse. In the type of discourse which Lacan refers to as "university discourse", for instance, $S_{2}$ (expert knowledge) assumes the (upperleft) position as Agent:

\begin{tabular}{l|l}
$\mathrm{S}_{2}$ & $a$ \\
\hline $\mathrm{S}_{1}$ & $\$$
\end{tabular}

In Inferno, this role is often played by Langdon, the academic expert, called upon to decipher encrypted messages produced by Zobrist $\left(\mathrm{S}_{1}\right)$, the one who knows (what is going to happen and why), but whose voice is repressed, ignored (that is: pushed into the lowerleft position). Rather than conversing with Zobrist directly, the latter is an absent Other, and Langdon's attention is primarily focussed on his bio-art gadgets: functioning as object $a$, or as its substitutes (upperright position): a series of contrivances containing crucial messages (Zobrist's legacy), such as the bio-tube described above (a piece of hypermodern bio-art, a bioluminescent pointer containing an 
unsettling message). But Zobrist's ultimate masterpiece (the novel's ultimate object $a$ ) is the designer virus, a high-tech artwork mid-way between living and non-living, natural and artificial, disastrous and beneficial, wholesome and poisonous; between salvation and destruction.

These bio-artworks have a disruptive, unsettling impact on Langdon: they trigger his unconscious desire, resulting in a craving subject (\$, lower-right position). At a certain point, for instance, his fascination goes so far that he even becomes a thief, stealing one of Zobrist's objects from a museum, something which a "normal", selfcomposed academic would never do (but we will come to this).

Thus, under the sway of the Other, Langdon unwillingly assumes the role of patient. As such, we see him awakening in hospital, feeling weakened and "incomplete" (Brown, 2013: 31), suffering from various deficiencies $(-\varphi)$ and symptoms, in need of a therapist and guardian. Now, Langdon is placed in the dominant position (upperleft) as a suffering, craving subject (\$) ("hysterical discourse"):

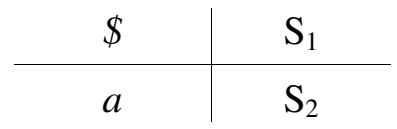

$\mathrm{He}$ is haunted by strange visions and fragmented messages he cannot ignore, coming from an unknown source, contained in weird contrivances (the objects $a$, now lower-left). He has lost his autonomy and is looking for someone (an authoritative Other) who, in this bewildering chaos, has the credibility to decide between right or wrong, good and bad ( $\mathrm{S}_{1}$, upper-right). It is Sienna's role (as therapist) to guide him, ask questions, tax his knowledge, so that, gradually, messages can be decoded, connections can be made and knowledge $\left(\mathrm{S}_{2}\right)$ is produced (lower-right).

As a therapist, however, roles are reversed again. Now it is Langdon's turn to enable Sienna (initially his personal mental therapist and body-guard) to play the role of craving agent (\$) who eventually confesses her "secret", the cause of her malaise, thus revealing her object $a$, that which she had been hiding (from). Her chronic malaise is first of all symbolised by a counterfeit pony she is wearing (as "partial", detachable object) to hide her baldness: the symptom of a medical condition known as "alopecia" which sheds light on her relationship with Zobrist (the questionable prophet, who gradually is taken increasingly seriously as an "authority", lower-right) and on her 
role in his movement (where she is known under the codename FS2080) ("analytical discourse"):

\begin{tabular}{c|c}
$a$ & $\$$ \\
\hline $\mathrm{S}_{2}$ & $\mathrm{~S}_{1}$
\end{tabular}

In the course of this paper, this scheme and its permutations will be further elaborated. In the final sections, I will summarise the results.

It is important to emphasise, however, that these roles are not merely individual roles, and that the novel is more than a series of (highly singular) fictional "case studies". These roles and voices represent broader societal trends. The focus is not on one particular individual expert, for instance, but rather on the role and dynamics of university discourse as such, and of global policy discourse as such. Thus, the novel does not present a series of quasi-realistic therapeutic files, but rather aims to register and analyse the complex "heteroglossia" of the technologically-advanced knowledge societies of today.

Throughout the novel, instances of "analytical discourse" question and challenge, subvert and permute other types of discourse. On the one hand, for instance, Robert Langdon is presented as an academic scholar giving voice to "university discourse". But as a scholar engrossed in the history of symbols, he suffers from unworldliness (an excessive attachment to the past), from which Sienna tries to cure him. Events and conversations act as eye-openers, allowing him to make his expertise "societally relevant" as it were, for instance by showing how the governance of contemporary virology (as a fascinating but highly uncanny "hyper-scientific" research field) may benefit from scholarly knowledge concerning similar episodes of crisis and collision in the past. Thus, his knowledge can contribute to the task of developing a comprehensive assessment of the present condition of human culture.

His "therapist" Sienna Brooks experiences a similar fate. Initially, she is presented as a biomedical expert: a superbly trained professional who knows how to deal with issues of health and survival quite effectively. Gradually, however, she becomes a "patient" herself: a former child prodigy who evolved into an enigmatic and talented, but also highly tormented person, suffering from fairly singular symptoms, with Robert as her "therapist". 
In the same way, Zobrist switches roles several times, from prophet and "master" (able to reveal the truth about the present human condition) to hysterical psychopath and back. And his key antagonist Elisabeth Sinskey likewise changes position: from global health expert to the embodiment of "denial" as a pandemic cultural affliction (that, at least, is how Zobrist, her self-proclaimed "therapist", sees her). Thus, step by step, in the course of series of analytic experiences and "sessions", the key characters are put on the track of their desire, their "object $a$ ". These therapeutic relationships will determine the design of my paper, with every section focussing on one particular "therapy":

\begin{tabular}{|c|c|c|c|}
\hline & "Patient" & "Therapist" & $\begin{array}{c}\text { Conceptual } \\
\text { backdrop }\end{array}$ \\
\hline $\begin{array}{c}1^{\text {st }} \\
\text { "therapy" }\end{array}$ & $\begin{array}{l}\text { Langdon as } \\
\text { unworldly expert } \\
\left(\delta^{\lambda}\right)\end{array}$ & $\begin{array}{l}\text { Brooks (physician) } \\
\text { (ㅇ) }\end{array}$ & $\begin{array}{l}\text { The therapeutic } \\
\text { novel: Gradiva }\end{array}$ \\
\hline $\begin{array}{l}2^{\text {nd }} \\
\text { "therapy" }\end{array}$ & $\begin{array}{l}\text { Brooks as craving } \\
\text { prodigy }(+ \text { ) }\end{array}$ & 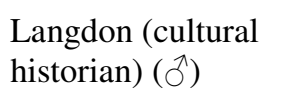 & $\begin{array}{l}\text { The matheme } \\
\text { of desire }\end{array}$ \\
\hline $\begin{array}{c}3^{\text {rd }} \\
\text { "therapy" }\end{array}$ & $\begin{array}{l}\text { Zobrist as mad } \\
\text { genius }(\hat{0})\end{array}$ & $\begin{array}{l}\text { Sinskey (health } \\
\text { policy expert) (ㅇ) }\end{array}$ & $\begin{array}{l}\text { Beyond the } \\
\text { pleasure } \\
\text { principle }\end{array}$ \\
\hline $\begin{array}{l}4^{\text {th }} \\
\text { "therapy" }\end{array}$ & $\begin{array}{l}\text { Sinskey: the } \\
\text { pandemic of denial } \\
\text { (q) }\end{array}$ & $\begin{array}{l}\text { Zobrist (virologist) } \\
\left(\AA^{\Uparrow}\right)\end{array}$ & $\begin{array}{l}\text { Designer virus } \\
\text { as an object } a\end{array}$ \\
\hline
\end{tabular}

The first "therapy" (upcoming section) will focus on Langdon as the unworldly scholar recovering from his unworldliness. Attention will be given to the temporal and topological setting of the novel: the story as it unfolds in time and space, revealing Langdon's excessive attachment to the past. Point of departure will be Freud's most elaborate analysis of a literary document, namely Wilhelm Jensen's novel Gradiva (Freud, 1907a [1906]). I will point out the extent to which Inferno resembles this precursory document about archaeology, love and reproduction, imbued with a fin-de-siècle atmosphere and published more than a century ago (in 1903).

In the subsequent section, it will be Langdon's role to support Sienna Brooks in uncovering her "object $a$ ", the cause of her desire, and of her discontent.

Next, the focus will shift towards Zobrist (the tormented scientific genius) as a "patient" (a dangerous psychopath) and director Sinskey as his "therapist". Their interaction brings some of the key 
("archetypal") concerns entailed in virology as a research field into view, notably the unsettling idea of a grand pandemic, a massive outbreak of lethal disease, a cataclysmal viral infection. But again, at a certain point, it is Zobrist's turn to become the "therapist", while Sinskey becomes the "patient". And as their original positions are reversed, the prospect of the viral pandemic undergoes a Gestaltswitch as well. It is now perceived in different terms: not as a disaster, but as the prelude to a new epoch. Initially, moreover, both research fields in question (cultural history represented by Langdon and virology represented by Zobrist) function as mechanisms of defence, keeping terrifying reality at bay, but gradually, they come to play a more or less opposite role: allowing (or even: forcing) us to face the imminent challenges ahead.

\section{First "therapy": awakening the unworldly expert} (the mutual exposure of past and present)

Sigmund Freud's most elaborate analysis of a literary text, and a paradigm for psychoanalytic literary criticism ever since, was devoted to Wilhelm Jensen's novel Gradiva, published in 1903 (Freud, 1907a [1906]). Interestingly, in terms of narrative structure, Inferno shares some striking similarities with Jensen's romance. Its key protagonist is an unworldly student of archaeology whose name coincidentally is an anagram (almost) of Robert Langdon: Norbert Hanold. This German scholar is intrigued (obsessed) by the image of a young woman displayed on an ancient relief. He dreams about her, and decides to go and look for her in Pompeii. In one of his dreams he witnesses how, during the fatal 79 A.D. eruption, her living body is covered with ashes and gradually transformed into marble. What he finds particularly fascinating about her is the way she strides and moves her feet, and he decides to call her Gradiva ("the striding one"). ${ }^{9}$ Upon arrival, Norbert finds the ancient site crowded by tourists, and yet, to his great astonishment, the encounter with Gradiva does take place. They meet a number of times, but after every conversation she suddenly disappears (through a breach in a wall, as he discovers later). Gradually, it dawns on him that she is not an apparition from the past, but a young tourist who went to Pompeii to "catch a husband" - an assignment in which she obviously succeeded.

9. A variant of the epithet of the Roman war-god Mars Gradivus (he who strides towards the field of battle). 
The congruencies between Gradiva and Inferno can be summarised as follows. Both novels feature a scholar absorbed in the past, represented in Gradiva by ancient ruins and in Inferno by medieval and early-modern monuments and symbols, with secret passages and hidden escape routes as a common topological feature. Both protagonists (bachelors) become fascinated by a mysterious young woman who keeps disappearing and returning (who is suddenly either Fort or $D a$, in a fairly unpredictable way). In fact, very much like Norbert, Robert is particularly struck by the way Sienna moves. And in his nightmares he is likewise haunted by visions of a statuesque woman. In both narratives, the heroes visit ancient sites (without a clear and convincing motive for doing so) where the past is very much "present", although the places are crowded by tourists, so that the issue of population growth becomes rather tangible and noticeable. Norbert and Robert meet and converse with their female antagonists among the monuments. These seem to come alive, displaying the scars and vestiges of previous traumatic calamities (the volcanic eruption in Gradiva, the bubonic Plague in Inferno).

Both Robert and Norbert are suddenly removed from their safe surroundings: a university campus (relatively immune from intrusions by the contemporary world), and transported to touristic localities where they become infected with the virus of romance, so that a rapport evolves. Yet, whereas Norbert and Zoë (Gradiva's real name, as he eventually discovers) become a couple, Robert remains single (all the main characters in Dan Brown's novel are cosmopolitan singles and destined to remain that way). Another difference involves time. More precisely: tempo and pace. Whereas in Gradiva all action is slowed down by a far niente, fin-de-siècle atmosphere and the heat of a siesta afternoon (the Mediterranean hour of the ghosts), in Inferno all action takes place at breath-taking speed: with everyone running (or at least walking very swiftly), chasing (or escaping from) each other all the time.

What can we gain from this comparison? Freud's basic contention regarding Gradiva is that it is the account of an (apparently successful) psychotherapy. At the start of the novel, Norbert has fallen prey to a delusion: a vision which makes him a captive of his dream world, inhibiting his ability to interact with real living human beings, notably women. His day-dreaming imprisons him in imaginary landscapes of the past, while keeping the bewildering and threatening contemporary world at a safe distance. Due to Gradiva's fascinating image, however, notably her foot as a "partial object", there is a first 
connection with contemporary reality, and he becomes keenly interested in the feet of women who pass him by in the streets, an interest which quickly evolves into a voyeuristic obsession - so that he becomes an object of ridicule in the eyes of the "victims" whose feet he wants to study. And yet, Gradiva's remarkable feet are nowhere to be found. They are the absent object of desire (the object $a$, in Lacanian grammar) defying transplantation from marble beauty into disenchanting reality.

Interestingly, in Inferno, this therapeutic dimension is fairly outspoken as well. Like Norbert, Robert's interests are firmly oriented towards the past: his kingdom is not of this world, so to speak. At the start of the novel, we find him suffering from delusions, apparently the result of a mysterious head-injury, which causes him to be hospitalised. Sienna (at his bedside) is questioning him, diligently taking notes. Like a psychologist (or even a psychoanalyst) she closely monitors his every word. Soon, verbalisation (free association, albeit not on a couch but in a hospital bed) gives way to other therapeutic phenomena, notably transference and acting-out. Langdon is taken from site to site, and this gradually enables him to reconstruct the missing parts of his story, recombining various fragments, and to recover from his amnesia. Rather than disclosing the truth directly, Sienna allows him to recover it by himself piece by piece as they go along, like a modern Oedipus as it were. Gradually, he is able to come to terms with the nightmares, weird messages and uncanny visions that besiege him.

But what really allows him to make the connection between past and present is Zobrist's oeuvre. Although the latter commits suicide early in the novel, he leaves a trail of encrypted messages behind: a legacy of bio-art gadgets, carriers of crucial information (a videotape, a bio-tube, and inscription on a death mask, and so on). Langdon's expertise in symbolism is called in to decode all this, but initially his knowledge falls short. Although highly fluent in medieval symbolism, he is illiterate when it comes to the symbolism of the present, of modern biochemistry (Brown, 2013: 50), leaving Zobrist in the advantage. The latter is not only a biochemistry virtuoso, but also a Dante expert. Like Dante himself, he is a polymath: a homo universalis of hypermodernity, an authoritative "Master" voice who knows the truth (in Lacanian grammar: $\mathrm{S}_{1}$ ). This exposure (enabled by Sienna) to contemporary bioscience ("mastered" by Zobrist) has a therapeutic effect on Langdon. It awakes him from his retrospective scholarly slumber. Gradually, the veil is lifted, and he is able to 
migrate from past to present, from phantasmagoria to reality, and from the late-medieval Plague era to the contemporary epoch of virology and biochemistry. His eyes are opened to developments of which he had hardly been aware (viral research, the Transhumanist debate, global health policies, and so on), but for which his historical knowledge can prove a valuable source of information: with the present as a repetition, an atavistic resurge of a traumatic, cataclysmic past. Like in the $14^{\text {th }}$ century, humankind has once again reached a decisive turning point. We are apparently faced with only two options: either Inferno or the Renaissance (to be brought about, this time, by biotechnological means).

\section{Second "therapy": a craving prodigy and the matheme of desire}

As the story unfolds, Robert Langdon becomes increasingly aware of Sienna Brooks, not as a fascinating "apparition", but as a real-life person, with a life-history of her own. Initially, she is introduced as a strong and independent woman, and described as "tall", "assertive" and "athletic" (Ibid.: 11), someone with "surprising strength" and a "firm hand" (Ibid.: 13), not only endowed with a superb physical condition, but also skilled in deadly martial arts (she eventually defeats and kills the dangerous woman, the secret agent clad in leather, for instance). At a certain point, however, a reversal of roles takes place. Now, it is Robert's turn to notice the anomalies of Sienna's increasingly erratic behaviour. For Sienna, the rapport between her and Robert is merely a side-track. She is a devoted disciple of Bertrand Zobrist (her Master, $S_{1}$ ). For a number of years, her involvement in the Transhumanist movement had eased her psychic problems, but now, her life is in pieces again, and her sense of purpose lost.

These roles and role reversals can be analysed with the help of Lacanian mathemes. ${ }^{10}$ Initially, from a Lacanian perspective, Norbert and Robert occupy the position of the "divided", craving subject $(\$)$, obsessed by a (seemingly hopeless) quest for a missing, irretrievable object (object $a$ ), the cause of their desire:

$$
\$ \diamond a
$$

10. "Mathemes" are algebraic formulae coined by Lacan for transmitting key concepts in a highly condensed, symbolical form (Roudinesco, 1993: 466). 
For Norbert the archaeologist, as we have seen, this object $a$ is a "partial object", a woman's foot, which suddenly comes to life as a captivating phantasm. This feature elevated Gradiva/Zoë to the position of enchanting Other (A), singling her out from the anonymous, disappointing others $(A)$ who pass the streets of modern city life in endless trains, but do not "have" it. Gradiva promises to be the Other (A) who may potentially satisfy the subject's desire, but whose existence seems highly improbable:

$$
\mathrm{A}+a=\mathrm{A}
$$

Her absence explained Norbert's impotence $(-\varphi)$, i.e., his inability to satisfy his own desire as well as the desire of others. The novel is essentially the tale of his recovery. Step by step, Zoë/Gradiva cures him from his delusion, so that his eroticism (foot fetishism) becomes incorporated in a full-fledged relationship with a real-life woman.

In the case of Robert Langdon, Sienna's ponytail works as her most prominent physical trait, mentioned remarkably often in Brown's novel and playing a similar role as Zoë's foot: the "partial object" that draws Robert's attention, the attribute that singles her out from others, the condensed symbol of her forbidding, athletic aura, the appendixlike (but, as we will see, detachable) object $a$. As an object $a$, it is a highly precarious item. At a certain point, it actually proves a counterfeit, a wig, an uncanny artefact, a cover-up of a feature that is actually missing: for Sienna is a patient, with baldness for a symptom. Now it is Sienna's turn to be portrayed as a craving subject (\$). Her baldness results from a long history of psychic suffering. At the age of seven, as a child prodigy endowed with exceptional intellectual gifts, she was diagnosed with depression. A psychiatrist suggested to drug her with Amitriptyline, but she already knew enough about pharmaceuticals to prevent this. As a young adult, she decides to focus on something practical: medicine, hoping to ease the suffering of troubled humankind. But her depression returns and she develops a condition known as telegenic effluvium or stress-related alopecia (i.e., baldness). She takes to wearing a fake blond ponytail, but suffers from her agonising deficiency, her lack, which makes her feel like "damaged goods" (Ibid.: 353). Her baldness (and the counterfeit tail as 
substitute) now becomes the symbol of this lack: ${ }^{11}$ the lack of coherence in her life, her fragmentation. ${ }^{12}$

Sienna is really a psychic puzzle. Initially, she is like a living athletic statue, but step by step, this image falls to pieces. Only her association with Zobrist had brought coherence to her life, notably his ethical algorithm developed to counteract the unsettling exponential curve of population growth: the "population apocalypse equation" (Ibid.: 177). Only Zobrist's visionary mathematics had provided her with a sense of purpose. As a genius, he had the rare power to really make a difference and achieve something of lasting value $(\varphi)$. He was not only endowed with superb mathematical and biochemical insights, but had a mission to fulfil, combining expertise in various branches of science and scholarship to produce his superb masterpiece of bio-art, his ultimate "gift" (midway between donation and poison, etymologically speaking) to humanity: the artificial virus, the novel's object $a$, the strange thing (hovering between living and non-living, good and evil) which everyone hopes to find. She reads everything he has written and Zobrist becomes her first lover. ${ }^{13}$ She is, in short, a Zobrist adept, a devoted member of his Transhumanist sect, and witnesses his suicide more or less like Maria Magdalen must have witnessed the crucifixion of Christ.

After Zobrist's death, having assisted him in carrying out his plans, she seems bereft of purpose once again. Her fake pony is the first piece of the puzzle that comes off. Her imaginary wholeness gives way to fragmentation (A $-a=\mathbb{A})$ and now it is Robert's "therapeutic" job to awake her from her infatuation, to bring her back to the real world of normalised human interactions. But she remains highly ambivalent about it all and keeps escaping him. This is exemplified by

11. "L'objet $a$ est quelque chose dont le sujet [...] s'est séparé comme organe [...] Il faut donc que ça soit un objet - premièrement, séparable - deuxièmement, ayant quelque rapport avec le manque (- $\varphi)$ " (Lacan, 1973 [1964]: 119). In Venice, Langdon and Sienna see the famous painting of Saint Lucia, carrying her eyeballs on a platter: the object $a$, her lust-inducing eyes, detached from her body, transformed into uncanny entities: "Here hast thou what thou so much desired" (Brown, 2013: 299). When her body was prepared for burial it was discovered that her eyes had been miraculously restored (cf Lacan, 2004 [1962-1963]: 205).

12. "Abruptly, Sienna reached up and grabbed a handful of her blond hair. Then she yanked down, and all of her hair slid off in a single motion. Langdon recoiled, startled both by the fact that Sienna wore a wig and by her altered appearance without it. Sienna Brooks was in fact totally bald, her bare scalp smooth and pale, like a cancer patient undergoing treatment" (Brown, 2013: 210).

13. "He coaxed from my inexperienced body a torrent of sensations that I have never imagined existed" (Brown, 2013: 355): an experience which in Lacanian language is known as jouissance. 
a scene in Istanbul, featuring Robert in pursuit of Sienna, trying to keep track of her (bald) head. Suddenly, she leaps off the dock, jumps on board a power boat, throws the driver overboard and takes off, only to return half-heartedly to Robert a few minutes later. ${ }^{14}$

In summary: Zobrist, Langdon and Sienna perform a number of roles that can be represented with the help of Lacanian algebraic symbols: $S_{1}$ (the authoritative voice), $S_{2}$ (established expert knowledge), $\$$ (the divided, craving, tormented subject) and $a$ (the object $a$, cause and target of desire). The relationship between Langdon and Sienna is beset with ambivalence: they act as a couple, but as key antagonists as well. But this applies to Bertrand Zobrist and Elisabeth Sinskey as well, whose roles will be the focus of the next two sections.

\section{Third "therapy": Bertrand Zobrist - psychopath or therapist?}

Zobrist aims to prevent the imminent cataclysm by curing the world from its "pandemic of denial". He disseminates a series of encrypted messages as wake-up calls, seeing himself not as a bioterrorist, but as a bio-therapist. Initially, the focus is on his role as mad genius: a "madman", a "maniac", a "very confused man" (\$), a psychopath about to abreact his personal malaise and discontent on society as a whole, a bio-terrorist who seems ready to unleash a plague with the help of a genetically modified virus, which he refers to as his "master-piece", a mysterious entity half-way between bioscience and art (the novel's object $a$ ). But this image is far from stable. On other occasions, Zobrist comes into view as a visionary, voicing a "Master discourse", a life-saving therapist, an enhancer of human culture, a harbinger of a new moral order $\left(\mathrm{S}_{1}\right)$.

Inferno is not a stand-alone novel, but part of a formulaic genre. Bioterrorism and "dual use" constitute topical literary themes. What will await us when (artificially modified) lethal bugs, intentionally released from the lab, pervade the outside world? In 1895, H.G. Wells already devoted his first science-fiction story (The stolen bacillus) to an "anarchist" who purloined a precious test-tube (containing a microbial object $a$ ) from a laboratory in order to wreak havoc in the London underground. Due to his scientific illiteracy, he steals the

14. Shortly before this scene, while still inside the cistern underneath Hagia Sophia looking for the viral liquid, Langdon himself is driven to the ground when Sienna suddenly "explodes" from her hiding place, accelerates into a sprint and "plowes" into him, before racing off towards the exit (Brown, 2013: 413), overrunning Sinskey on her way out as well. 
wrong tube, so that an innocent variant of the pathogen is released. For the time being, the object $a$ of bioscience escapes him and the uncanny powers of virology remain a latent threat.

Since then, however, virology has evolved into a thriving and highly prestigious hyperscience, attracting "showers of funding" (Quammen, 2012: 77). In Spillover, David Quammen announces the advent of a whole series of viral threats, including Ebola, emerging against the backdrop of major societal transitions such as population growth, globalisation, increased global mobility, climate change and ecological disruption. A global population of seven billion people is tearing ecosystems apart, Quammen argues, unloosing viral life forms into the global environment at an unprecedented pace, so that the term "zoonotic spillover" (viral migration from animal hosts to humans) will become "a word of the future, destined for heavy use in the twenty-first century" (Ibid.: 21). For Quammen, viral zoonosis represents "the most significant growing threat to global health" (Ibid.: 44). To these demographical and ecological causal factors, concerns over bioterrorism must be added: the intentional release of hazardous viral strains into the environment.

In this arena of looming threats, virology plays an ambiguous role. On the one hand it is a "mechanism of defence", immunising us from lethal infections and potential bioterrorist attacks. And yet, rather than strengthening our sense of safety, it often has the opposite effect. First of all by revealing the existence and magnitude of previously unknown dangers, for viral life thrives all around us, while known viruses constitute only a small sample of what is out there. Potentially lethal viruses may be hiding for extended periods of time before suddenly resurging, due to the astonishing pace with which they can evolve and adapt to emerging opportunities. In addition, there is the vivid concern that viral knowledge, data and strains, processed in virology laboratories around the globe, may fall into the wrong hands, so that virology, rather than safeguarding us from dual use, may encourage and enable it. A famous recent case was the global turmoil over the avian flu virus, created for the purpose of preparing ourselves for a future pandemic, mentioned in Inferno (Fouchier, 2012).

And yet, by way of compensation, and as a prophylaxis against panic, there is an inherent inclination in contemporary culture to ignore such threats. In Beyond the pleasure principle, Freud (1920g) already argues that, in contrast to views that emphasise human curiosity and world-openness, the human psyche basically functions as an immunisation mechanism, a mechanism of defence, keeping the 
threatening outside world at bay. Although our sense organs allegedly allow us to see and hear the world, they primarily work in the opposite direction, by warding off disconcerting external signals, allowing only small samples of reality to enter our sensory system. Their basic purpose is to filter out the information we need and disregard the rest. We are equipped with eyes and ears because they allow us not to see and not to hear (Matthew 13:13).

This is underscored by human anatomy. We are almost completely covered by "blind" protective skin, in combination with artificial protective layers known as cloths. Our sense organs are miniature apertures, whose primary purpose is to provide protection against overstimulation (Reizschutz). This tendency of organisms to insulate themselves from the outside world already applies to microorganisms, coaxed inside their cell membranes. First and foremost, our vulnerable bodies have to be protected against the tendency towards entropy: the relentless pressure on living things to dissolve into inorganic debris. Protection against external stimuli is a life task at least as important as sensitivity and receptivity (Freud, 1920g: 27). Our sense organs are like little antennae that select small samples of exteriority, allowing us to assess it in minute quantities. Our primary objective is to safeguard bodily integrity from external traumas, including viral intrusions.

From a psychoanalytical perspective, a virology lab is a special type of environment, almost completely encapsulated, effectively immunised against intrusions from the outside world, a constellation of technologically enhanced "sense organs", devices of extreme precision, allowing only tiny samples of reality to enter, so that they can be subjected to meticulous analysis. Only a few favoured viral strains, considered worthy of closer inspection, are allowed to dwell there, as objects of choice of the viral cupido sciendi (the virologists' will to know). At the same time, it is a locus suspectus, an uncanny site where possibly dangerous viral life forms are cultured, such as the "lab-bred flu" already mentioned (Butler, 2011; Hunter, 2012), which triggered Dan Brown to write Inferno. In fact, Inferno essentially is a novel about "dual use", featuring a bioterrorist who uses his viral knowledge and biotechnological dexterity to consciously bring about an infertility pandemic. 
"Immunisation" is one of the most ancient organic processes of life, but it can only be partially successful. ${ }^{15}$ Infectious diseases continue to scourge human habitats. In the $19^{\text {th }}$ century (the era of Pasteur and Koch), quite effective artificial techniques for enhancing the human immune system were developed, such as inoculation, promoting population growth worldwide. Whereas infectious diseases tended to curb human population density at regular intervals, from now on the unsettling image of the exponential growth curve announced itself, a mathematical figure that not only applies to population growth as such, but also to everything connected with it, such as pollution, deforestation, mass extinction and so on. Bertrand Zobrist, the mad genius of the novel, basically employs the tools of virology to counteract the outcome of their previous use, namely overpopulation. He encounters an obstacle on his way, however, a psychic mechanism of immunisation: denial.

Therefore, he arranges a meeting with powerful public health official Elisabeth Sinskey to lecture her about the logic of exponential curves, drawing a terrible conclusion, his plea to "cull" the human herd, but Sinskey tries to awake him from his morbid dreams and to convince him that a global human population of seven billion must be considered a reality. Instead of being given the floor, Zobrist becomes the target of a manhunt. Sinskey acts as the bureaucrat $\left(S_{2}\right)$, ignoring (repressing) Zobrist's unsettling "truth". Notwithstanding the countless "anomalies" that are accumulating, she cannot go beyond accepted knowledge. Zobrist on the other hand claims to speak on behalf of a wholly new scientific and political paradigm which he has founded $\left(S_{1}\right)$. The question therefore is whether he really is a new type of leading voice or rather a psychopath $(\$)$.

Fourth "therapy": the policy of denial

At this point, roles begin to shift. Zobrist now becomes the "therapist" rather than the "patient". First of all, we are informed about Elisabeth Sinskey's own medical history. Suffering from severe asthma at the age of six, she was treated with a promising drug

15. One could argue that life itself began as a kind of inflammation, an infection of our planet by pioneering life forms, resulting in the greening of oceans, and eventually covering the abiotic earth with films of living matter. Subsequently, however, to maintain themselves, all living entities developed protective measures to prevent their genomes and enzymes from degradation. Eventually, death (entropy) is inevitable, but immunisation allows organisms to postpone this inevitable outcome of the process of living. 
containing steroid hormones, causing irreparable damage to her reproductive system. "Time will heal the emptiness", the doctor had assured her (Brown, 2013: 99), but presently, sixty-one years old, she "still felt the pang of hollowness every time she saw a mother and infant" (Ibid.). The "inconceivable" child had become her object $a$.

As WHO director, she embodies the widespread attitude of denial. Zobrist's message, substantiated by mathematical evidence, amplified by unsettling artistic images, is that uncurbed population growth has brought us on the brink of extinction. A cataclysmic collapse is awaiting us, due to lack of resources (the "oral" dimension) in combination with excessive pollution (the "anal" dimension), unless dramatic action is taken. During his personal meeting with Sinskey, Zobrist uses a Doré lithograph, displaying a horrid scene from Dante's Inferno, to make his point. His secret plan is to unleash a viral infection causing infertility. In the longer run, genome-engineering will eliminate our congenital flaw (over-abundant reproduction). By that time, humankind will have entered the post-human era, taking evolution into our own hands. This is the quintessence of his ethical algorithm: sacrifice (the fertility of) one-third of current humanity to safeguard survival and well-being of future generations, a line of reasoning also defended by Sienna in her debates with Langdon and Sinskey. ${ }^{16}$ The only obstacle blocking the path to salvation is the ubiquity of denial. Seeing that officials like Sinskey refuse to listen to him, he decides to curb fertility directly, thus by-passing our psychic propensity to ignore disturbing information.

Zobrist accuses the world's leaders of "extreme denial" (Ibid.: 215). Notably the WHO acts as a global censor, driving prophets such as Zobrist underground, so that his communication style becomes increasingly extravagant. Freudian terminology is literally used: denial figures as a mechanism of defence, employed to ward off disturbing ideas (Ibid.: 214), which are therefore bound to resurge as symptoms. ${ }^{17}$

16. "For Years", Sienna argues, "Bertrand Zobrist attempted to engage with influential people to discuss the impending crisis. He visited countless organisations that he believed could effect change $[\ldots]$ but he never found anyone who dared engage in a meaningful conversation $[\ldots]$ They all responded with plans for better contraception and even talk of colonizing the moon! [...] He begged to engage you [Dr. Sinskey] in some kind of dialogue, but rather than listening to his ideas, you [...] put him on a watch list and drove him underground $[\ldots]$ instead of [admitting] that our catastrophic circumstances might actually require an uncomfortable solution [...] Bertrand was ostracised" (Brown, 2013: 449).

17. "The human mind has a primitive ego defense mechanism that negates all realities that produce too much stress for the brain to handle. It's called denial [...] Denial is a critical part of 
One of the most noticeable is mass tourism. During their visit to Venice, Robert and Sienna are confronted with "throngs" of people (Ibid.: 305) and Langdon begins to wonder whether Zobrist may have a point in warning about overpopulation. ${ }^{18}$

Zobrist is the Perseus of hypermodernity, beheading Medusa, the uncanny chthonic goddess of fecundity (Ibid.: 436), while comparing the virus he releases to the severed head, the uncanny and disconcerting "partial" object which he is now holding in his hand. ${ }^{19}$ Eventually, however, human fertility must be "pruned" on the more basic, genomic level. Viral vectors will put an end to our current impotence as a species $(-\varphi)$ to do something about it. They will empower us $(\varphi)$, paving the way for the advent of a new, enhanced humanity. In Zobrist's algebra: $\mathrm{H}^{+}$.

Meanwhile, the hunt for Zobrist and his airborne virus continuous. WHO acts as a phobic organisation, unwilling/unable to cope with today's challenges. The only truly countervailing power, ready to counteract the impending catastrophe, is Transhumanism. Ironically, this movement is itself depicted as an epidemic, a contagious ideology (which, in the case of Bertrand and Sienna, proves "sexually transmissible"). Although Transhumanism so far has been a marginal, "academic" phenomenon, it is about to "explode from the shadows into the mainstream" (Ibid.: 453). One of its fundamental tenets is that "we as humans have a moral obligation to participate in our evolutionary process [...] to use our technologies to advance the species, to create better humans" (Ibid.: 453). Genetic engineering will help us to "engineer our own bodies so we can survive in a changing world" (Ibid.). We will finally be able to overcome our chronic discontent as a species: more in tune with its socio-technological

the human coping mechanism. Our minds block out our existential fears by focusing on stresses we can handle [...] on simple tasks and daily trivialities" (Brown, 2013: 214).

18 . Venice hosted a staggering number of tourists every year - an estimate one-third of one percent of the world's population - some twenty million visitors in the year 2000. With the additional billion added to the earth's population since that year, the city was now groaning under the weight of three million tourists per year. Venice, like the planet itself, had only a finite amount of space, and at some point would no longer be able to import enough food, dispose of enough waste, or find enough beds for all those who wanted to visit it (Brown, 2013: 306).

19. Medusa plays a double role. She is the goddess of fertility, i.e., the chthonic force fuelling our exponential population curve, but the designer virus is compared to her head (the detached object $a$ ); and Zobrist uses the one to overcome the other. The virus is an invisible monster, residing in a subliminal, primeval "underworld" (Brown, 2013: 279), a ground zero, as a looming threat, from where life emerged (Ibid.: 409). "Normal" virology aims to transform the lethal virus into a benign one by stripping it of its lethal genes. 
environment (Ibid.: 454). Through "assisted evolution" (Ibid.: 293), a new Renaissance awaits us.

In the end, Zobrist's therapy seems to work. Sienna (his "substitute") is offered amnesty and Sinskey invites her to join her to an upcoming WHO meeting, offering her a seat at the table. A new moral framework has to be developed, and this requires "a new breed of thinkers". Denial is about to give way to the reality principle, so it seems. Meanwhile, Langdon himself flies back to Harvard. In his case, the therapy (aimed at reconnecting him with the contemporary world of global governance) apparently failed after all.

\section{Resume: Inferno's basic structure in terms of the four discourses}

Our analyses of the various roles and positions can now be summarised and further elucidated with the help of Lacan's "four discourses", involving four variables in different positions (truth, agent, other, product), as described above:

\begin{tabular}{c|c} 
Agent & Other \\
\hline Truth & Product
\end{tabular}

-the master signifier $\left(S_{1}\right)$;

-established expert knowledge $\left(\mathrm{S}_{2}\right)$;

-the divided (craving) subject (\$);

-the object (cause, focus) of desire (object $a$ ).

Through permutations, the four discourses can be generated. One by one, the other discourses are subverted/challenged/permuted by analytical discourse, so that the actors are put on the track of their object $a$, the cause of their desire.

After analysing the results, I will focus on "analytical" discourse, where $a$ assumes the dominant position (as "agent"). But I will start my resume with the Master discourse:

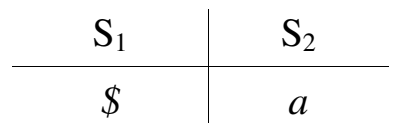

As we have seen, Bertrand Zobrist, as authoritative "Master"-voice $\left(\mathrm{S}_{1}\right)$, occupies the (upper-left) position (Agent), the one who knows the truth, knows what is happening and why. Throughout the novel, 
his videotaped soliloquy serves as an authoritative source of information (as a techno-scientific version of the Book of Revelation as it were). But this is only one item in a whole series of encrypted messages containing decisive cues, inviting "experts" $\left(S_{2}\right)$ to come to terms with the situation (upper-right position). The expert role $\left(\mathrm{S}_{2}\right)$ is allotted to Robert Langdon, recruited by WHO-director Elisabeth Sinskey. Thus, an encryption-decryption game evolves. Zobrist seems to forge his messages (contained in sophisticated devices) especially for him.

But there is a personal, even pathological dimension to his "truth", an element of (repressed) personal malaise, an obsession even, pushing Zobrist into a different role, namely that of the mad genius, the psychopath (\$). As long as Zobrist plays the role of Master, this dimension is repressed (contained in the lower-left position). Once it becomes dominant, his discourse becomes subverted (permutated) so that the quadrant turns 90 degrees. In this position, Zobrist becomes entangled in a "hysterical" discourse (as will be described below).

As a by-product (lower-right position) of the Master discourse, a number of fascinating objects (objects $a$ ) are produced, such as the bio-tube, but also Dante's death mask (carrying a coded message) and, finally, the genetically modified airborne virus.

Next comes the university discourse (left-hand turn):

\begin{tabular}{l|l}
$\mathrm{S}_{2}$ & $a$ \\
\hline $\mathrm{S}_{1}$ & $\$$
\end{tabular}

Robert Langdon is now in the dominant position (Agent) as scholar $\left(S_{2}\right)$ : the expert from Harvard, the academic researcher of international renown, called upon to decipher the encrypted cues. His attention is directed towards a series of objects $a$ (now in the upper-right position), fascinating entities containing crucial signifiers, carriers of valuable information, such as visions of protruding legs ("partial objects"). These visions are caused by a benzodiazepine injection, as he eventually finds out. Other carriers of valuable, intriguing cues are the bio-tube (displaying the map of Hell) and Dante's death mask (bearing an - barely readable, apparently nonsensical - inscription). Langdon's expert knowledge is based on authoritative sources (ancient documents, $S_{1}$ ), but these are not mentioned directly: they have been processed into standard academic ("normal") expertise. 
By way of by-product, a number of symptoms are produced (lower-right): professional pathologies, notably his scholarly unworldliness, so that the apparently self-composed Langdon unwillingly becomes a craving subject (\$), divided between past and present, in need of support from others to reconnect with the contemporary world, and prone to develop erratic behaviour unexpectedly (such as theft).

All characters are being pushed into a hysterical discourse sooner or later. The scheme is permutated in such a way that the emphasis shifts towards their personal malaise, their inability to cope with the challenges involved in their station in life:

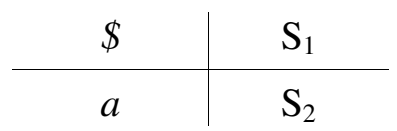

The Agent is now a divided, tormented subject (\$). This first of all applies to Zobrist, who is seen by many (including Langdon) as a psychopath $(\$)$, a faltered prophet, someone whose messages sound like cries of despair, who is obsessed by the highly unlikely, indeed: paranoid conviction that he is on the dead list of the WHO and persecuted by specialised squads of WHO agents.

All characters become craving, tormented subjects ("patients") at a certain point, in need of an authoritative voice, a reliable Other who can put them on the right track again $\left(\mathrm{S}_{1}\right.$, upper-right). This applies to Langdon, for instance. Waking up at the start of the novel, he is bereft of his intellectual and physical prowess $(-\varphi)$, suffering from various psychic symptoms (amnesia, hallucinations, etc.), needing help. One of these symptoms is claustrophobia, a debilitating fright for cramped spaces (Brown, 2013: 164), a paralyzing inhibition that destabilises him at crucial moments. ${ }^{20}$

At a certain point, Sienna (initially his body-guard and therapist) moves into the hysterical position, as we have seen. Her symptoms (baldness, depression, lack of purpose) now become the focus of attention. The counterfeit pony tail functions as a metaphor which, in a highly condensed form, summarised her history of malaise.

20. We are informed that his claustrophobia was caused by a childhood trauma (Brown, 2013: 164). It is a professional handicap, moreover, since "symbological" research frequently involves visits to cramped, damp and murky spaces. From a psychoanalytic perspective, his career choice may well be regarded as compensation, similar to asthma patients becoming top athletes (Adler, 2006 [1920]). 
Eventually she confesses that, rather than treating Langdon's memory problems, she actually was the one who induced them in the first place (by injecting him with benzodiazepines).

Last but not least, the type of discourse that pervades the novel in various manners is the analytical discourse. All characters play the role of therapists every now and then, allowing others to acknowledge and come to terms with their (impossible) desire: their object $a$. Other types of discourse are relentlessly challenged, subverted and permutated by analytic discourse, so as to bring the object $a$ into focus, as the ultimate (unconscious) cause of all (inter)actions.

Robert Langdon assumes the role of analyst as soon as he begins to realise that, as a "university expert", he will fail to understand Zobrist's weird messages. In order to understand the "method" in his madness, he must relinquish (repress) his role as expert $\left(\mathrm{S}_{2}\right)$, pushing it into the lower-left position:

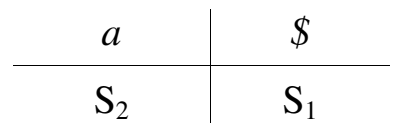

Instead of relying on standard knowledge, he must learn to approach Zobrist with an open mind, a listening ear, probing him from an oblique angle as it were, making sure not to interpret too soon (as experts usually tend to do). This means that Zobrist's contrivances become something very singular and special. These devices themselves now assume the dominant role as "Agents" (upper-left position), guiding others towards the truth, not as mere gadgets, but as things containing an imperative; a call for action: READ ME! Indeed, According to Lacan, this is how (in the contemporary world) the Master discourse now speaks to us: via "gadgets": minute electronic things forged by technoscience (Lacan, 1991 [1969-1970]: 174).

Thus, the novel as such is pervaded by analytical discourse, subverting the other discourses so that, one by one, the key characters are put on the track of their object $a$, enabling them to discern their hidden desire, their libido sciendi, their craving for insight and knowledge.

The object a as "Actor"

From an analytical perspective, the novel's most decisive instances of "agency" are embodied in Zobrist's devices: messages encased in 
bio-art. These are the things that trigger and orchestrate human action. They carry the signifiers that allow "analysts" to reconstruct Zobrist's motives and views. This applies, for instance, to the bio-tube: an optic device using fluorescent micro-organisms to beam up (bring to life) a Renaissance artwork, depicting suffering and death.

At a certain point, Dante's death mask assumes the role of object $a$. According to Lacan, an object $a$ is basically a bodily part (a "partial organ", or its substitute), catching and drawing our attention, but replaceable and detachable (up to a certain point). It is always connected with an experience of lack. This goes for Sienna's counterfeit (detachable) pony, as we have seen. According to Lacan, during early childhood (the oral stage), the mother's breast functions as the paradigmatic object $a$. It can be either present or absent, and is replaceable by substitutes to some extent, such as comforters: standins for the natural original, mimicking its shape. In Gradiva, the object $a$ was a young woman's foot, captured in (replaceable by) a marble replica.

A death mask perfectly falls within this set. It captures the gaze of the Other, immortalising it in plaster. This plaster has been caked onto

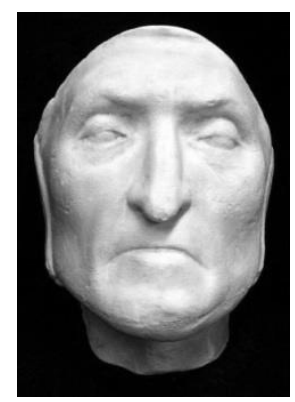
the skin shortly after death. Once hardened, it is detached from the face and used as a mould into which fresh plaster is poured. As a replica of a face, it is uncanny (Freud, 1919h). Through his death mask, Dante continues to stare at us, as if he is still among us, although his eyes are empty, absent in a way. As if it is possible somehow to take off someone's face. This object $a$ captures the gaze of the poet who envisioned an enigmatic, frightening landscape (Inferno), transforming it into poetry. There is always the possibility that this plaster replica is a counterfeit, however, a replica of the original (being itself a replica of the poet's face). It symbolises, in a condensed form, the boundary between life and death, real and unreal, original and artefact. It is both priceless and completely useless.

Dante's death mask plays a role similar to that of the famous skull represented (albeit in a concealed, anamorphic manner) on Holbein's The Ambassadors, discussed by Lacan (1973 [1964]) as the painting's object $a$. On the left and right side of the painting: two Renaissance scholars/officials. Between them, early modern gadgets: research 
devices, scientific artworks. ${ }^{21}$ In front of them the skull, only recognisable as such from an oblique angle, and functioning as a vanitas-symbol: memento mori. For Lacan, it represents the ultimate impotence of science $(-\varphi)$ to defeat death (Lacan, 1973 [1964]: 102), a counterpoint to the scientific and artistic splendour on display in the rest of the painting: a question-mark added to early

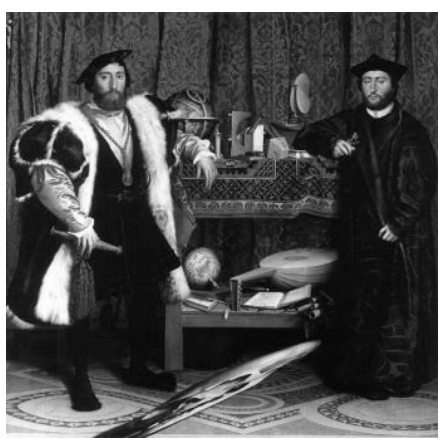
modern self-complacency. By presenting two powerful, autonomous human beings, our vulnerability and mortality seem eclipsed, but the skull is the return of this repressed dimension..$^{22}$ Holbein's skull is an add-on, moreover: there and not there, seen and unseen.

The uncanny objects owned or produced by Zobrist (the videotape, the bio-tube, ${ }^{23}$ the death mask) all share this memento mori feature: we are heading for disaster, and normal science and policy $\left(S_{2}\right)$ are unable $(-\varphi)$ to do anything about it. All these uncanny items symbolise, in a condensed and metaphorical way, the imminent catastrophe.

This also applies to Dante's death mask. It is on display in a small corridor: visitors can only see it in passing, from an oblique perspective as it were. It is a priceless object, but almost hidden from view. And there is always the possibility that this unique and valuable, but precarious possession might be counterfeit, or even stolen. Objects $a$ may suddenly be missing. This is what happens in the novel. First of all, Zobrist buys it, although he decides to leave it where it is.

21. As Lacan phrases it, art mingles with science: "L'art ici se mêle à la science" (Lacan, 1973 [1964]: 99); "Or, dans le tableau des Ambassadeurs [...] les deux personnages sont figés, raidis dans leur ornements monstrateurs. Entre eux toute une série d'objets qui figurent dans la peinture de l'époque les symboles de la vanitas. Corneille Agrippa, à la même époque, écrit son De vanitate scientarum, visant autant les sciences que les arts, et ces objets sont tous symboliques des sciences et des arts tels qu'ils étaient à l'époque groupés" (Ibid.: 101-102).

22. For Lacan, the skull plays a similar role as Cornelius Agrippa's De vanitate scientiarum, emphasising the powerlessness of science, published in this same period, but applying only to the sciences of the day, not to their rival approach, the repressed field which Cornelius Agrippa himself represented, namely alchemy. Zobrist is the Cornelius Agrippa, the alchemist of Inferno, defying standard discourse and normal science, but developing an alternative (a combination of biotechnology and Transhumanism) that will grant us control over life and death.

23. On the video-tape, Zobrist appears in the guise of the plague doctor, wearing a plague mask, while the bio-tube contains a bioluminescent organism that projects a high-definition photograph of Hell. 
Nonetheless, some privileges are granted to him in connection with his ownership, such as the privilege to hold it, to inspect and admire it. But then, suddenly, it is really gone. The question is: who stole the stolen mask? A new research assignment for Langdon.

Langdon is absolutely intrigued by Dante's mask, falling victim to its alluring aura. For by-standers, it is incomprehensible why it holds such a fascination for him (Brown, 2013: 165). He spends almost an hour studying it closely, but due to his amnesia, he remembers nothing about it the following day. But the whole episode is videotaped. The seemingly unseen (the theft) was actually seen. In the novel, structured as a therapy, this forgotten scene (erased from Langdon's memory files) is reconstructed step by step, with the help of the museum's panoptic video footage. Langdon sees himself visiting the museum after hours, and finds it "deeply unsettling to watch himself doing things of which he had absolutely no recollection". Standing right in front of the mask, he puts on a pair of surgical gloves and steals it, so that in the display case, only absence and emptiness remain. In other words, he discovers that he actually is the criminal himself. Why has the mask become such a highly singular object of fascination $(\$ \diamond a)$, to the extent that he even commits a crime to lay his hands on it? Answer: because Zobrist has left a message at the back of the mask. Suddenly, the death mask becomes more than a mere historical item; it becomes the embodiment of a moral imperative, engraved in plaster: STEAL ME! The mask (as object $a$ ) assumes the role of agent (upper-left position), forcing Langdon to do something which otherwise would seem inconceivable: namely commit an offence, purloin a priceless item from a museum, something which may well ruin his career as an academic. Rather than as an expert, however, he is now acting as an analyst. By gazing through the mask, Zobrist will come into view. With the help of this mask, a genuine dialogue unfolds with the craving psychopath (upperright position), who left an enigmatic message on the plaster: PPPPPPP. Indeed, as Lacan argues, pathological discourse is basically a cryptogram. Langdon understands that this (apparently meaningless) string of signifiers actually refers to the letters carved on Dante's forehead as he entered purgatory. The signifier P stands for Peccatum and signifies "sin". Every time Dante ascends one level, one of these Ps is cleansed from his forehead (like a tainted gene that is erased), until he is ready to enter Paradise. By paying due attention to objects $a$, as carriers of pieces of code, heeding the symbolic references they contain, Langdon discerns what Zobrist the bioterrorist is up to. The 
unintentional end-result (lower-right position) is that Zobrist is increasingly taken seriously, that he gradually becomes a respected Master-voice $\left(S_{1}\right)$ after all. Towards the end of the novel, even Sinskey is cured from her denial, so that she invites Sienna (Zobrist's stand-in, as it were) to join her at an important WHO meeting. For Sienna, this brings a new sense of purpose to her life.

In the end, however, even the death mask is a mere substitute for the ultimate object $a$, namely the designer virus. Viruses are relics of the very first life-forms: vestiges of distant evolutionary epochs, when life first made its appearance on earth and "minimal" genomes invaded and ruled the world through self-replication. It is questionable whether they can be regarded as organisms at all: they are "partial" living objects, fundamentally dependent on the cells and bodies of their hosts for their survival. We fear these entities, try to repress them, immunise ourselves against them, but cannot do without them. For Zobrist, as we have seen, the designer virus becomes his lifework, his opus, his obsession.

Max Delbrück, the quantum physicist from Germany who became the founding-father of molecular biology in the U.S., also opted for a virus as his model organism: the minimal biological entity, the proton of biology (Fischer, 1985; Zwart, 2013). Whereas Delbrïck founded the molecular life sciences (bent on understanding/analysing life at the molecular level), Zobrist features in Inferno as founding-father of virology as a hyperscience, bent on drastically refurbishing, reprogramming and resynthesizing life (Zwart, 2012). Interestingly, his symbol for post-humanity is $\mathrm{H}^{+}$, which is also the symbol for the proton. It is the beginning and conclusion (A and $\Omega$ ) of the history of life and nature as we know it (Zwart, 2013). It is humanity (H), but stripped of its genetic flaw (its propensity to over-reproduce, $\mathrm{e}^{-}$): $\mathrm{H}-$ $\mathrm{e}^{-}=\mathrm{H}^{+}$. A new body, a new Self $\left(\mathrm{H}^{+}\right)$will allow us to overcome our current insufficiency, our lack. Thus spoke Zobrist.

\section{Implications for virology}

So far, focussing on the novel, virology as such was studied from an oblique angle so to speak. In this final section, I want to bring virology more explicitly into view, as an imaginative "hyper-science" $\left(\mathrm{S}^{+}\right)$, rather than "normal" science $\left(\mathrm{S}_{2}\right)$. As normal science, virology would be a variant of "university discourse", with virology experts $\left(\mathrm{S}_{2}\right)$ in the (upper-left) position, as "Agents": fascinated by, and devoting their lives to, working with (genetically modified) viruses as 
model organisms, bred and studied in the lab ( $a$ in the upper-right position):

\begin{tabular}{l|l}
$\mathrm{S}_{2}$ & $a$ \\
\hline $\mathrm{S}_{1}$ & $\$$
\end{tabular}

Although these viruses may be potentially lethal, they are firmly contained in the fridges and flasks of normal science, from which there can be no escape. Biosecurity and biosafety are in place; the experts $\left(\mathrm{S}_{2}\right)$ are in control. Research projects are inspired by a moral imperative $\left(S_{1}\right.$, coming "from beneath"): in order to immunise the world from viral threats, we must replicate and meticulously study them. This type of work is fairly monotonous and repetitive, rather than exiting or imaginative: "normal" in every respect.

In Inferno, presenting virology as a societal phenomenon, active within the public sphere, this scheme becomes subverted and disrupted. The uneasiness persists that containment may prove hazardous and that the precious entity (virology's object a) may assume a more commanding role, switching over to the upper-left position, sending out a provocative appeal: STEAL ME! It may fall into the wrong hands, or seduce researchers to move beyond the safety boundaries of normal science. This unsettling possibility produces chronic discontent ( $\$$, lower-right position), as an unintended byproduct of viral research.

To address it (instead of discarding it as "misguided", as normal university discourse tends to do), Inferno challenges researchers to permute the quadrant (leftward turn) and to opt for a more analytical perspective:

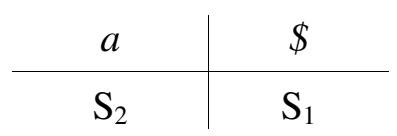

Now, the discontent $(\$)$ of the Other is explicitly addressed. By allowing outsiders to move to the upper-right position, scientists are prepared to "face" them, to take them more seriously (as Other), so that a real dialogue (a genuine interaction) may ensue. The expert's conviction $\left(\mathrm{S}_{2}\right)$ that we already "know" (and are perfectly able to contain) the risks, is suspended (moved towards the lower-left position) so that the focus can be shifted to the question: what exactly is it that we find so unsettling and "post-normal" about virology and 
its object $a$ (the genetically modified virus)? Openness and sensitivity towards outsider concerns is given more space. It is acknowledged that viral research (involving potentially lethal viruses, such as the H5N1 avian flu virus) oversteps the boundaries of normal science. These viruses are not studied in a completely neutral fashion, as is to be expected from "normal" science. And this is why researchers working in this area are bombarded by rules and regulations and besieged by invitations from journalists (not to mention anonymous hostile e-mails). Contemporary societies have become over-concerned with safety, relying on science and technology to keep viral threats at bay. Safety has evolved into a cultural obsession. Thus, science and technology may overdo it, becoming an issue of concern in their own right.

There clearly is a moment of truth in virus phobia. Outsider concerns may recognise that our will to know is fuelled by a latent destructive "death drive": a hidden aggressiveness. The H5N1 virus, isolated in the lab, already draws the voyeuristic gaze of global mass media towards it. It may well become a target of choice for Zobristlike prophets (potential bioterrorists), susceptible to the moral imperative it embodies: come and find me! They may use lethal viral strains as vectors for their global wake-up call. And this concern may result in even stricter rules and regulations (even more phobic and neurotic) enforcing safety, which will only underscore the potential significance of these viral materials even more. ${ }^{24}$ The scientific will to knowledge is fuelled by a will to power (over life and death), and the experience of breeding potentially lethal viruses in a laboratory fridge is a rather singular one. Beneath the expert $\left(\mathrm{S}_{2}\right)$, there is a craving subject $(\$)$ and although most experts will be perfectly trustworthy individuals, there is always the possibility that Mr. Hyde, this Jungian "shadow" as it were, gains the upper hand.

This type of scenario is acted out in Inferno. The novel's value does not reside in its factual correctness (experts may point out various factual irregularities no doubt), but rather in its ability to flesh out how lethal viruses (as object $a$ ) gain sway over the imagination (of scientists as well as outsiders). For indeed, even viral experts themselves are prone to experience the power of the things which they

24. Cf the line discovered on an Al-Qaeda hard-disk: "We only became aware of [biological weapons] when the enemy drew our attention to them by repeatedly expressing concerns that they can be produced simply". http://www.theatlantic.com/magazine/archive/2004/09/inside-alqaeda-s-hard-drive/303428/ 
are stashing in their fridges or circulating around the globe. Their work will continue to make the headlines, not because of superb academic quality, but because these potentially viral strains (in their own exhibitionistic way) keep drawing attention to themselves. Unlike the tested bugs of normal science, the lethal viruses themselves dominate the scene. The researchers involved are drawn towards studying them, even if this means putting up with additional loads of paperwork and committee hearings that come with working with potentially dangerous viral strains.

Virologists may argue that their project is very much like any other project, adhering to the logic of university discourse (as reflected in the Lacanian scheme), and that there is no reason for this type of research to be singled out for extra surveillance, or to attract hatemail. They clearly would want to clinch to the profile of university discourse: just doing their job as academic researchers $\left(S_{2}\right)$. But this is impossible. They work with a "Genie", an exceptionally powerful entity that may escape its bottle. Their object of research (their virus of choice) is an object $a$. And this is what makes their work both fascinating and unsettling, for outsiders as well as for themselves.

The lethal virus, cultured in the labs of experts such as Ron Fouchier, is an object $a$ for various reasons. First of all, as a virus, it is something which may become part of our own bodies, as minute partial objects, entering our bodies as host organisms, while at the same time remaining something detachable, coming from outside. In Lacanian language: a virus is an "extimate" entity (Lacan, 2006 [19681969]), both intimate and foreign, both internal and external. It represents the boundary between living and non-living, between inside and outside, between that which promotes and that which threatens health (both on an individual and on a collective level).

Like Dante's death mask, the flu virus is a memento mori, moreover, a condensed symbol, a metaphor of human mortality, an unsettling reminder of earlier pandemics, with their tremendous death toll, rendering medicine completely powerless. Finally, it is something midway between an organism and a device - a device, moreover, which contains a decipherable code: the genome that can be studied, processed and manipulated in the lab. Rather than seeing public uneasiness as a troublesome "by-product" of virology research (occupying the lower-right position in "university discourse"), a much more optimal option is to enter into a genuine dialogue to address societal concerns, placing outsiders in the upper-right position, that is: opting for analytical discourse. 


\section{Bibliography}

A. Adler (2006 [1920]), Praxis und Theorie des Individual-Psychologie, Frankfurt am Main, Fischer.

W. Bowsky (1971), The Black Death: A Turning Point in History?, New York, Holt, Rinehart and Winston.

D. Brown (2013), Inferno, New York, Doubleday.

D. Butler (2011), "Fears grow over lab-bred flu", Nature, vol. 480, pp. 421-422.

S.N. DeWitte (2014), "Mortality Risk and Survival in the Aftermath of the Medieval Black Death", PLoS ONE 9(5): e96513. doi:10.1371/journal.pone.0096513

E.P. Fischer (1985), Licht und Leben. Ein Bericht über Max Delbrück, den Wegbereiter der Molekularbiologie, Konstanz, Universitätsverlag Konstanz.

R. Fouchier (2012), "Preventing pandemics: The fight over flu" Nature, vol. 481, pp. 257 259.

S. Freud (1907a [1906]), Der Wahn und die Träume in W. Jensens 'Gradiva', G.W., VII, pp. 29-122.

S. Freud (1919h), "Das Unheimliche", G.W., XII, pp. 229-268.

S. Freud (1920g), Jenseits des Lustprinzips, G.W., XIII, pp. 1-70.

P. Hunter (2012), "H5N1 infects the biosecurity debate", EMBO reports, pp. 1-4.

W. Jensen (1903), Gradiva, Frankfurt, Fischer.

J. Lacan (2004 [1962-1963]), Le Séminaire, Livre X, L'Angoisse, texte établi par J.-A. Miller, Paris, du Seuil.

J. Lacan (1973 [1964]), Le Séminaire, Livre XI, Les quatre concepts fondamentaux de la psychanalyse, texte établi par J.-A. Miller, Paris, du Seuil.

J. Lacan (2006 [1968-1969]), Le Séminaire, Livre XVI, D'un Autre à l'autre, texte établi par J.-A. Miller, Paris, du Seuil.

J. Lacan (1991 [1969-1970]), Le séminaire, Livre XVII, L'envers de la psychanalyse, texte établi par J.-A. Miller, Paris, du Seuil.

S. Mawer (2005), "Science in literature: interview", Nature, vol. 434, pp. 297-299.

D. Quammen (2012), Spillover. Animal infections and the next human pandemic, New York/London, Norton.

J. Rohn (2006), "Experimental fiction", Nature, vol. 439, pp. 269.

E. Roudinesco (1993), Jacques Lacan: Esquisse d'une vie, histoire d'un système de pensée, Paris, Fayard.

H.G. Wells (1895), The stolen bacillus and other incidents, London, Methuen.

H. Zwart (2008), Understanding nature. Case studies in comparative epistemology, Dordrecht, Springer.

H. Zwart (2012), "On decoding and rewriting genomes: A psychoanalytical reading of a scientific revolution", Medicine, Healthcare and Philosophy: A European Journal, vol. 15 , no. 3 , pp. 337-346.

H. Zwart (2013), "The genome as the biological unconscious - and the unconscious as the psychic 'genome'. A psychoanalytical rereading of molecular genetics", Cosmos and History: The Journal of Natural and Social Philosophy, vol. 9, no. 2, pp. 198-222.

H. Zwart (2014), "Limitless as a neuro-pharmaceutical experiment and as a Daseinsanalyse: on the use of fiction in preparatory debates on cognitive enhancement", Medicine, Healthcare and Philosophy: A European Journal, vol. 17, no. 1, pp. 29-38. 